\title{
Na AkzoNobel: meer bescherming vereist voor beursvennootschappen?
}

\author{
H. Koster
}

\section{$1 \quad$ Inleiding}

In 1971 discussieerden de bestuurders van de Koninklijke Shell over de kwestie of het toegestaan was om gelden die door de aandeelhouders aan de vennootschap waren toevertrouwd voor olieactiviteiten te gebruiken voor andere activiteiten. Was diversificatie toegelaten? Zij vonden dat dit kon. Het argument was:

'that in a modern society, the large public corporation had a "life" of its own, directed by its management; and that in exercising this direction management had responsibilities not only to shareholders but also to employees and to the community. (...) All three of these responsibilities would be properly discharged by applying the corporation's asset of sound and long-experienced managerial skills to some additional good purpose, always assuming that this other purpose was prudently selected having regard to the talents and experiences possessed by the company. ${ }^{.1}$

De vraag naar de reikwijdte van de bevoegdheden van het bestuur levert zo'n 45 jaar later nog steeds discussie op. De recente belangrijke uitspraak van de Ondernemingskamer van het Gerechtshof Amsterdam van 29 mei 2017 (Elliott International L.P. c.s./AkzoNobel NV, hierna: Elliott c.s. en AkzoNobel) ${ }^{2}$ over de klacht van activistische aandeelhouders en hedge funds Elliott c.s. dat AkzoNobel niet wil onderhandelen over de voorwaarden om een PPG-bod te steunen, illustreert dat fraai. ${ }^{3}$ In de kern ging het er daarbij eigenlijk om of het bestuur, onder toezicht van de raad van commissarissen $(\mathrm{RvC})$, naar huidig recht voldoende middelen heeft om een eigen lijn te trekken als zich een niet-welkome bieder meldt

1 S. Howarth \& J. Jonker, Powering the hydrocarbon revolution, 1939-1973. A history of Royal Dutch Shell. Volume 2, Oxford: Oxford University Press 2007, p. 373.

2 Hof Amsterdam 29 mei 2017, ECLI:NL:GHAMS:2017:1965.

3 Ook de politiek en werkgeversorganisatie VNO-NCW lieten in dit kader van zich horen. Zo noemde de toenmalige minister Henk Kamp (Economische Zaken) het bod van PPG op AkzoNobel niet in het Nederlandse belang gezien de bijdrage van het bedrijf aan duurzaamheid, R\&D en hoogwaardige werkgelegenheid. Werkgeversvoorzitter Hans de Boer zei dat buitenlanders Nederlandse bedrijven voor een koopje willen overnemen. Toenmalig minister Jeroen Dijsselbloem noemde de buitenlandse overnemende partijen zelfs 'aasgieren'. Zie 'Haagse stress over Unilever en AkzoNobel', FD 13 maart 2017. 
dan wel of Nederlandse beursvennootschappen meer bescherming behoeven. ${ }^{4}$ In dit artikel zal ik deze vraag beantwoorden. Ik zal daartoe in de volgende twee paragrafen eerst de stand van zaken bespreken met betrekking tot de reikwijdte van de bevoegdheden en taken van de organen van een beursvennootschap in het kader van het perspectief van een mogelijke overname en soortgelijke situaties. Vervolgens zal ik in paragraaf 4 de vraag beantwoorden of meer bescherming vereist is. Ik sluit in paragraaf 5 af met een conclusie.

\section{Rolverdeling vennootschapsorganen}

\subsection{Het werkterrein van het bestuur}

Uitgangspunt is dat het bestuur het vennootschapsorgaan is dat belast is met het besturen van de vennootschap behoudens beperkingen volgens de statuten. Daarnaast heeft het bestuur een onbeperkte en onvoorwaardelijke bevoegdheid om de vennootschap te vertegenwoordigen bij het aangaan van rechtshandelingen, tenzij uit de wet anders voortvloeit. ${ }^{5}$ Het bestuur moet over dit beleid verantwoording afleggen aan de algemene vergadering, maar is in beginsel niet verplicht de algemene vergadering vooraf bij zijn besluitvorming te betrekken als het gaat om zaken waartoe het bestuur bevoegd is. ${ }^{6}$ Bij de vervulling van de aan het bestuur bij wet of statuten opgedragen taken moet hij het belang van de vennootschap en de daaraan verbonden onderneming vooropstellen en de belangen van alle betrokkenen, waaronder die van de aandeelhouders, bij zijn besluitvorming in aanmerking nemen. ${ }^{7}$ Voorts is het bepalen van de strategie (in beginsel) een aangelegenheid van het bestuur, waarop de RvC toezicht houdt en waarover de algemene vergadering haar opvattingen tot uitdrukking kan brengen door uitoefening van de haar in de wet en statuten toegekende rechten. ${ }^{8}$

\subsection{Het werkterrein van de RvC}

De $\mathrm{RvC}$ heeft tot taak toezicht te houden op het beleid van het bestuur en op de algemene gang van zaken in de vennootschap en de met haar verbonden onderneming. Hij staat het bestuur - gevraagd en ongevraagd - met raad ter zijde. Bij de

4 Zo stelde Jan Hommen voor: 'In geval van bijvoorbeeld een ongewenst bod, zou een onderneming beroep moeten kunnen doen op een bepaling die voorziet in een dergelijke bedenkpauze, bijvoorbeeld een jaar. Zo'n bepaling zou tamelijk snel in de Nederlandse Corporate Governance Code kunnen worden opgenomen, en dus ook in de wet kunnen worden verankerd. Een onafhankelijke instantie als bijvoorbeeld de Autoriteit Financiële Markten, de AFM, zou zo'n periode kunnen begeleiden, en eventueel een eenmalige verlenging van maximaal 180 dagen kunnen geven als blijkt dat de onderneming inderdaad meer tijd nodig heeft om op deugdelijke wijze alternatieven uit te werken en alle belangen evenwichtig en terdege mee te nemen.' Zie 'Hommen: "Ontdoe een overname van alle hijgerigheid", FD 28 maart 2017.

$5 \quad$ Zie art. 2:129 en 2:130 BW.

$6 \quad$ HR 13 juli 2007, ECLI:NL:HR:2007:BA7970 (ABN AMRO), r.o. 4.3.

7 HR 9 juli 2010, ECLI:NL:HR:2010:BM0976 (ASMI), r.o. 4.4.1. In dit kader kan ook worden gewezen op de Cancun-uitspraak van de Hoge Raad. Ik citeer: 'Indien aan de vennootschap een onderneming is verbonden, wordt het vennootschapsbelang in de regel vooral bepaald door het bevorderen van het bestendige succes van deze onderneming.' Zie HR 4 april 2014, NJ 2014/286. 
vervulling van hun taak richten de commissarissen zich naar het belang van de vennootschap en de met haar verbonden onderneming. Deze wettelijke taak brengt echter niet met zich mee dat de $\mathrm{RvC}$ de verplichting heeft een bemiddelende rol te vervullen bij conflicten tussen het bestuur en de aandeelhouders. Dit zou in strijd zijn met de vrijheid die de $\mathrm{RvC}$ heeft voor het uitvoeren van zijn toezichttaak. De $\mathrm{RvC}$ is hierover aan de aandeelhouders ook geen verantwoording verschuldigd. ${ }^{9} \mathrm{De} \mathrm{RvC}$ kan door de aandeelhouders wel worden benaderd met verzoeken om te bemiddelen en zal dan adequaat vanuit zijn eigen taakopdracht moeten handelen. De RvC heeft in dergelijke situaties, gelet op zijn verantwoordelijkheid jegens de vennootschap en de met haar verbonden onderneming, de vrijheid om van geval tot geval een afweging te maken of rechtstreeks contact met de aandeelhouders en/of bemiddeling tussen aandeelhouders en bestuur wenselijk zijn, gelet op het belang van de vennootschap en de met haar verbonden onderneming. ${ }^{10}$

\subsection{Het werkterrein van de algemene vergadering}

Het uitgangspunt is dat aan de algemene vergadering alle bevoegdheid toebehoort, binnen de door de wet en de statuten gestelde grenzen, die niet aan het bestuur of aan anderen is toegekend. ${ }^{11}$ De algemene vergadering heeft een aantal belangrijke bevoegdheden, zoals in het kader van emissie van aandelen, statutenwijziging, bezoldigingsbeleid, ontbinding, aangifte tot faillietverklaring, vaststelling jaarrekening, juridische fusie en splitsing en de goedkeuringsbevoegdheid die voortvloeit uit art. 2:107a van het Burgerlijk Wetboek (BW). In het kader van samenwerking geldt evenwel dat het bestuur van een vennootschap rechtens niet gehouden is het aangaan van een joint venture ter instemming of goedkeuring aan de algemene vergadering voor te leggen, wanneer die joint venture past in het profiel van de gebruikelijke en normale ondernemingsactiviteiten van de vennootschap..$^{12}$ Daarnaast is er in de regel geen verplichting tot voorafgaande consultatie van de algemene vergadering in het geval dat het bestuur van een vennootschap geen medewerking wil verlenen aan een in de openbaarheid gebracht onderhands bod op een wezenlijk deel van de activiteiten van de vennootschap. ${ }^{13}$ In dit kader is relevant dat afwijzing van een dergelijk bod in de regel meebrengt dat in de wezenlijke kenmerken van de vennootschap en in het profiel van de daaraan verbonden onderneming geen verandering wordt gebracht, laat staan een wijziging van zo ingrijpende aard dat instemming vooraf of goedkeuring achteraf van de algemene vergadering vereist zou zijn. ${ }^{14}$ Het bestuur en de RvC zijn wel gehouden aan de algemene vergadering alle verlangde inlichtingen te verschaffen, tenzij een zwaarwichtig belang van de vennootschap zich daartegen verzet. $^{15}$ 
Daarbuiten hebben aandeelhouders geen recht op het verstrekken van door hen afzonderlijk verlangde informatie. ${ }^{16}$

\section{Spelregels tijdens overnamesituaties}

\subsection{Enkele inleidende opmerkingen}

Bij een overname of een (potentieel) openbaar bod is sprake van een bijzondere situatie. Er wordt een bod uitgebracht of voorbereid op alle aandelen van een (beursgenoteerd) bedrijf. ${ }^{17} \mathrm{Bij}$ een dergelijke overname is doorgaans sprake van een driehoekssituatie. Omdat het doorgaans praktisch gezien onmogelijk is om met alle aandeelhouders te onderhandelen, onderhandelt de koper met het bestuur van het bedrijf, terwijl het bestuur in de regel niet de aandelen in de vennootschap bezit. Bij een openbaar bod heeft een bieder over het algemeen het oogmerk om door het verwerven van de aandelen een fusie of overname te bewerkstelligen. ${ }^{18}$ Het bod is niet gericht tot specifieke personen, maar wordt (in beginsel) uitgebracht aan alle aandeelhouders. ${ }^{19}$ Het is aan de doelvennootschap om de aandeelhouders te laten weten of zij het bod al dan niet steunt. ${ }^{20}$ Vervolgens zijn de aandeelhouders aan zet en kunnen zij het bod afwijzen of erop ingaan. ${ }^{21}$ Tijdens een overname vervullen het bestuur en de $\mathrm{RvC}$ een belangrijke rol. De $\mathrm{RvC}$ zal een proactieve houding moeten aannemen ${ }^{22}$ en zich intensiever moeten bemoeien met het overnameproces. ${ }^{23}$ Commissarissen kunnen eigen initiatieven nemen. ${ }^{24} \mathrm{Er}$ bestaan op dit gebied overigens geen concrete spelregels voor de RvC. De RvC zal vooral moeten afgaan op de algemene regels over zijn

16 HR 9 juli 2010, ECLI:NL:HR:2010:BM0976 (ASMI), r.o. 4.6.

17 Hierna zal ik alleen ingaan op beursondernemingen.

18 W.B. Kuijpers \& A. van der Krans, 'De positie van minderheidsaandeelhouders en het openbaar bod', O\&F 2014, afl. 1, p. 19-31.

19 Er bestaan vier verschillende soorten openbare biedingen, het betreft: volledig bod, partieel bod, tenderbod en verplicht bod. Van een verplicht bod is sprake als de aandeelhouder over overwegende zeggenschap beschikt. Het meer of minder houden dan $30 \%$ van de aandelen is bepalend voor het soort bod. Een bod kan van vriendelijke of vijandelijke aard zijn.

20 Art. 18 en bijlage G, onder 1, Bob.

21 Voor het openbaar overnamebod zijn de belangrijkste bepalingen in de Wet op het financieel toezicht (Wft) en het Besluit openbare biedingen (Bob) opgenomen.

22 Zo lagen de commissarissen van Ten Cate in dit kader onder vuur. De RvC zou te passief hebben gehandeld. Zie J. Bos, 'Wrevel over rol commissarissen bij overname van Ten Cate', FD 25 november 2015.

23 J.L. Burggraaf, 'De rol van de raad van commissarissen bij een onderneming in financiële moeilijkheden', in: G. van Solinge e.a., Herstructurering van ondernemingen in financiële moeilijkheden, Deventer: Kluwer 2014, p. 105-118. Zie ook Hof Amsterdam (OK) 15 februari 2013, ECLI:NL:GHAMS:2013:BZ1149 (Van der Moolen), r.o. 9.3.9 en 9.5.2.

24 Zie ook Hof Amsterdam (OK) 28 december 2006, ECLI:NL:GHAMS:2006:AZ5413 (KPNQwest), r.o. 3.47. 
taken en open gedragsnormen, ${ }^{25}$ omdat Boek 2 BW geen formele taakomschrijving bevat voor de $\mathrm{RvC}$ bij een openbaar bod. ${ }^{26}$

In het verleden is voorgesteld om in de Nederlandse Corporate Governance Code (hierna: de Code) enkele regels hierover op te nemen. ${ }^{27}$ Deze hielden in dat bij een overname de $\mathrm{RvC}$ toezicht dient te houden op (1) de gevolgen van een overname voor de strategie van de onderneming, (2) de beoordeling van de wenselijkheid van een overname, (3) het onderhandelingsproces bij overnames en (4) de verhoudingen met (minderheids)aandeelhouders en andere betrokkenen bij de onderneming rondom het overnameproces. ${ }^{28}$ Naar aanleiding van de reacties op de consultatie heeft dit onderdeel de Code niet gehaald. Er zou nog niet op alle punten voldoende best practice bestaan. ${ }^{29}$ Wel werd in de Code in 2008 opgenomen dat wanneer een overnamebod wordt voorbereid, het bestuur er zorg voor moet dragen dat de $\mathrm{RvC}$ tijdig en nauw wordt betrokken bij het overnameproces. Daarnaast werd opgenomen dat het bestuur in het geval een derde bieder zich aanbiedt direct contact moet opnemen met de RvC. Mocht de derde bieder een verzoek doen om inzage te krijgen in de gegevens van de vennootschap, dan moet het bestuur dit verzoek en de bijbehorende gegevens met de $\mathrm{RvC}$ bespreken.

\subsection{Lessen uit de jurisprudentie: bescherming kan (tijdelijk) toegestaan zijn}

Uit de jurisprudentie vallen enkele lijnen te destilleren die tezamen mijns inziens een redelijk functioneel kader bieden. Een eerste uitgangspunt is dat een doelvennootschap onder bepaalde omstandigheden beschermingsmaatregelen ${ }^{30}$ mag treffen om tegen te gaan dat een onwelgevallige bieder een overwegende of belangrijke mate van zeggenschap in haar verkrijgt. ${ }^{31}$ Dit om (1) tijd te geven voor kennisname van de voornemens van de bieder, (2) te kunnen overleggen over diens opvattingen over het door hem wenselijk geachte beleid en (3) daarover met de medeaandeelhouders te (kunnen) overleggen, en (4) alternatieven te onderzoeken. ${ }^{32}$ Overigens is in de literatuur ook opgemerkt dat het bestuur er is om aan-

26 M.W. Josephus Jitta \& B.R. van der Klip, 'De rol van het bestuur en de raad van commissarissen bij een openbaar bod', in: M.P. Nieuwe Weme e.a. (red.), Handboek openbaar bod (Serie Onderneming en Recht, deel 46), Deventer: Kluwer 2008, p. 299-300.

27 Uit de toelichting blijkt dat het verband hield met de ontwikkelingen in 2007 ten aanzien van overnames van beursvennootschappen. De Commissie achtte het van belang dat bestuur en $\mathrm{RvC}$ een zorgvuldige afweging maken van de belangen van alle bij de vennootschap betrokkenen, in het bijzonder aandeelhouders, werknemers en crediteuren.

28 Zie het rapport van de monitoringscommissie uit 2008. Zie ook R.G. Nowak, 'Het rapport van de Commissie-Frijns over de actualisering van de corporate governance code', Ondernemingsrecht 2008/125.

29 De Nederlandse Corporate Governance Code 2008, p. 52.

30 Zie uitgebreid over beschermingsmaatregelen Asser/Maeijer, Van Solinge \& Nieuwe Weme 2 II* 2009/631-676 en M. van Olffen, Beschermingsmaatregelen in de 21e eeuw, Deventer: Kluwer 2000.

31 Dit was onder meer het geval bij de strijd tussen RNA en Westfield. Zie HR 18 april 2003, NJ 2003/286 (RNA).

32 Hof Amsterdam (OK) 11 maart 1999, NJ 1999/351 (Breevast) en Hof Amsterdam (OK) 27 mei 1999, NJ 1999/487 (Gucci II). 
deelhouders te beschermen die hun aandelen willen verkopen, maar die de waarde van de onderneming niet begrijpen, of die daartoe niet in staat zijn. ${ }^{33}$ Het gebruik van een beschermingsmaatregel kan gerechtvaardigd zijn als deze maatregel noodzakelijk is, onder meer met het oog op de continuïteit van (het beleid van) de vennootschap en de belangen van degenen die daarbij betrokken zijn. ${ }^{34}$ Dit geldt ook als de vennootschap voor een open (onbeschermde) structuur heeft gekozen. ${ }^{35}$ Dit betekent mijns inziens ook dat een beschermingsmaatregel niet alleen bij een potentieel vijandig bod gehanteerd kan worden, maar ook in andere situaties waar de continuïteit (van het beleid) op het spel staat, zoals bij een voorgenomen ontslag van bestuurders/commissarissen. Wel zal van gewicht zijn met welk doel de beschermingsconstructie in het leven is geroepen en met welk doel zij vervolgens wordt aangewend. ${ }^{36}$ Een tweede uitgangspunt is dat het gedurende een onbepaalde tijd handhaven van een beschermingsmaatregel in het algemeen $^{37}$ niet gerechtvaardigd zal zijn. ${ }^{38}$

\subsection{Lessen uit de jurisprudentie: bescherming dient gerechtvaardigd te zijn}

Een derde uitgangspunt is dat de vraag of een beschermingsmaatregel gerechtvaardigd is, ${ }^{39}$ moet worden beantwoord aan de hand van de omstandigheden van het geval. Daarbij zal met name moeten worden afgewogen, en dit is in rechte marginaal toetsbaar, of het bestuur van de vennootschap - maar dit geldt mijns

33 R.J. Gilson \& R. Kraakman, 'Delaware's intermediate standard for defense tactics: Is there substance to proportionality review', The Business Lawyer (44) 1989, p. 247.

34 Uit Gucci II blijkt dat de opkomst van een verwerver met een belang van ongeveer 34,4\%, die daarmee in feite een controlerende positie innam, een valide reden kan zijn om over te gaan tot het inzetten van een beschermingsconstructie. Zie Hof Amsterdam (OK) 27 mei 1999, NJ 1999/487 (Gucci II).

35 HR 18 april 2003, NJ 2003/286 (RNA), r.o. 3.7.

36 Zie over een uitspraak van de Ondernemingskamer of het is toegestaan om een beschermingsmaatregel te treffen ter bescherming van de belangen van minderheidsaandeelhouders Hof Amsterdam (OK) 16 juni 2010, JOR 2010/229 (Cascal).

37 Door het gebruik van de woorden 'in het algemeen' lijkt de Hoge Raad de mogelijkheid open te houden dat dit in uitzonderlijke gevallen anders (dus wel voor onbepaalde tijd) kan zijn.

38 HR 18 april 2003, NJ 2003/286 (RNA) en Hof Amsterdam (OK) 17 januari 2007, JOR 2007/42 (Stork). Zie ook de conclusie van A-G Timmerman bij ASMI: '3.7.12 (...) De bescherming zal in het algemeen langer geoorloofd zijn naarmate het bestuur meer concessies doet aan de aandeelhouder(s), zonder dat hier concessies van de aandeelhouder(s) tegenover staan. Omgekeerd zal de bescherming in beginsel minder lang geoorloofd zijn naarmate de aandeelhouder meer concessies doet, zonder dat het bestuur beweegt. Daarnaast kan de opstelling van de ondernemingsraad, van overige aandeelhouders, in het bijzonder die van lange termijn-aandeelhouders, en andere direct belanghebbenden van invloed zijn op de vraag of een bescherming kan worden gehandhaafd en hoe veel concessies van de ene of andere partij kunnen worden gevergd. Naarmate andere bij de vennootschap betrokken belanghebbenden meer steun uitspreken voor een van partijen, zal wellicht gevergd kunnen worden dat de andere partij meer beweegt teneinde tot een oplossing te komen. Ook de reactie van partijen op de standpuntbepaling van de andere belanghebbenden kan op die manier invloed hebben op de vraag hoe lang de bescherming mag voortbestaan.'

39 Zie over de vraag of een gebruikte optie op aandelen opnieuw kan worden aangewend, G. van Solinge \& M.P. Nieuwe Weme, 'Voortdurende opties', in: Vertrouwen in het ondernemingsrecht en financiële recht. Liber amicorum prof. mr. S.C.J.J. Kortmann (Serie vanwege het Van der Heijden Instituut, deel 150), Deventer: Wolters Kluwer 2017. 
inziens ook voor de stichting continuïteit ${ }^{40}$ - in redelijkheid heeft kunnen oordelen dat het nemen van de beschermingsmaatregel noodzakelijk was om in afwachting van de uitkomst van verder overleg met de partij die de zeggenschap poogt over te nemen, en met andere betrokkenen, de status quo te handhaven en aldus te voorkomen dat - zonder voldoende overleg - wijzigingen worden gebracht in de samenstelling van het bestuur of in het tot dan toe gevoerde beleid van de onderneming, welke wijzigingen naar het oordeel van het bestuur van de vennootschap niet in het belang zouden zijn van de onderneming of van degenen die bij de onderneming betrokken zijn. ${ }^{41}$ Als maatstaf voor (1) het nemen en (2) het vooralsnog handhaven van een beschermingsmaatregel geldt dat dit gerechtvaardigd is, als deze maatregel in de gegeven omstandigheden bij een redelijke afweging van de in het geding zijnde belangen (nog) valt binnen de marges van een adequate en proportionele reactie op het dreigende gevaar van een ongewenste overname. Hierbij wordt niet alleen gekeken naar de eerste reactie van het bestuur op de poging tot overname, maar met name ook naar het beleid dat het bestuur in verband met, en in vervolg op, het creëren van een status quo heeft gevoerd en op de zorgvuldige afweging van de betrokken belangen op grond van een beoordeling van feiten en omstandigheden die, zoals in het onderhavige geval ook is gebleken, aan snelle veranderingen onderhevig kunnen zijn. ${ }^{42}$ Onder dit beleid valt in het bijzonder de taak dat het bestuur ervoor zorg draagt dat zowel de minderheidsaandeelhouder die de zeggenschap in de onderneming tracht te verkrijgen, als de overige aandeelhouders voldoende geïnformeerd worden over de wederzijdse standpunten. ${ }^{43}$ Dit betekent voorts dat het nemen van maatregelen die op gespannen voet staan met regels van (dwingend) recht en/of in strijd zijn met de eisen van redelijkheid en billijkheid kunnen wijzen op een onjuist beleid. ${ }^{44}$ Een en ander betekent mijns inziens ook dat een beschermingsmaatregel is toegestaan als nog onvoldoende overleg is gevoerd en onvoldoende inzicht bestaat in de voornemens van de bieder. Daarnaast kan een maatregel toegelaten zijn indien de voornemens van de bieder gevaar kunnen opleveren voor de continuïteit van (het beleid van) de vennootschap en de belangen van degenen die daarbij betrokken zijn. Dit betekent ook dat als het overleg is vastgelopen, er nog steeds reden kan zijn om vast te houden aan de beschermingsmaatregel. Het lijkt erop - door het gebruik van de woorden 'onder meer'45 - dat zelfs als de continuïteit niet in het geding is, een beschermingsmaatregel toch onder omstandigheden gerechtvaardigd kan zijn. 2017/47.

41 HR 18 april 2003, NJ 2003/286 (RNA), r.o. 3.7.

42 HR 18 april 2003, NJ 2003/286 (RNA), r.o. 3.7.

43 HR 18 april 2003, NJ 2003/286 (RNA), r.o. 3.7.

44 Hof Amsterdam (OK) 27 mei 1999, NJ 1999/487 (Gucci II), r.o. 3.16. 


\subsection{Lessen uit de jurisprudentie: bescherming kan worden getoetst door de rechter}

Het inzetten en gebruiken van beschermingsmaatregelen - maar ook andere issues die samenhangen met aandeelhoudersactivisme, ${ }^{46}$ zoals pogingen om bestuurders en/of commissarissen te ontslaan - kan door de rechter worden getoetst. Sinds in 1994 in het enquêterecht onmiddellijke voorzieningen werden toegestaan, wordt de vraag of het gebruik van beschermingsmaatregelen geoorloofd is doorgaans in enquêteprocedures beantwoord. Uit de RNA-uitspraak van de Hoge Raad blijkt dat ook het incidenteel nemen of handhaven van beschermingsmaatregelen, zonder directe zeer ernstige gevolgen, tot wanbeleid kan leiden. ${ }^{47}$ Het toepassen van beschermingsconstructies moet verantwoord zijn en worden gekenmerkt door een zorgvuldige belangenafweging en een genoegzame motivering voor de uiteindelijke keuze. ${ }^{48}$ Voor de doeleinden van het enquêterecht heeft overigens te gelden dat een beschermingstichting niet als medebeleidsbepaler van de vennootschap wordt aangemerkt. ${ }^{49}$ Het relevante criterium bij een enquêteprocedure is of sprake is van wanbeleid. Van wanbeleid is sprake bij onzorgvuldig dan wel laakbaar handelen dat een zo ernstig karakter heeft dat er sprake is van strijd met elementaire beginselen van verantwoord ondernemerschap. ${ }^{50}$ Dit wordt in de regel marginaal getoetst. Dat geldt ook voor de vraag of sprake is van gegronde redenen om aan een juist beleid of juiste gang van zaken te twijfelen. ${ }^{51}$ Dit onder meer omdat verschillend gedacht kan worden over de vraag waar de beleidsvrijheid van de ondernemer precies ligt. Die grens kan verschuiven als gevolg van veranderingen of ontwikkelingen in het rechtsbewustzijn. ${ }^{52}$

\subsection{Lessen uit de jurisprudentie: bestuur is 'in the lead'}

Bij strategische besluiten om het 'standalone'-scenario te verlaten en een fusie aan te gaan, of een bod op de aandelen uit te lokken of te accepteren, is het bestuur, handelend met instemming van de $\mathrm{RvC}$, bevoegd. ${ }^{53}$ Het bestuur is niet gehouden om de algemene vergadering vooraf bij de besluitvorming daarover te betrekken. ${ }^{54}$ Wel geldt dat het bestuur ook in deze situaties bij de vervulling van zijn bij wet of statuten opgedragen taken het belang van de vennootschap en de

46 Zie bijv. Hof Amsterdam (OK) 17 januari 2007, JOR 2007/42 (Stork).

47 HR 18 april 2003, NJ 2003/286 (RNA).

48 Zie ook M.J. van Ginneken, Vijandige overnames, Deventer: Kluwer 2010, p. 39.

49 HR 9 juli 2010, ECLI:NL:HR:2010:BM0976 (ASMI), r.o. 4.7.

50 HR 10 januari 1990, NJ 1990/466 (OGEM).

51 Zie hierover ook de conclusie (3.1.6) van A-G Timmerman bij HR 9 juli 2010, ECLI:NL:HR: 2010:BM0976 (ASMI). Ik citeer daaruit: 'Bij de beoordeling van het beleid van de vennootschap geldt dat een vennootschap in beginsel een grote mate van beleidsvrijheid heeft, vanzelfsprekend binnen de grenzen van de wet en met inachtneming van de rechten van derden. In het verlengde hiervan geldt in beginsel hetzelfde voor organen van de vennootschap en de personen die daarbij zijn betrokken. Uit het principe van beleidsvrijheid volgt dat een oordeel dat er wél gegronde redenen bestaan om te twijfelen aan een juist beleid een grondiger motivering behoeft dan een oordeel dat hiervan géén sprake is.'

52 Zie Kamerstukken II 1991/92, 22400, 3, p. 8.

53 HR 13 juli 2007, ECLI:NL:HR:2007:BA7970 (ABN AMRO), r.o. 4.3.

54 HR 13 juli 2007, ECLI:NL:HR:2007:BA7970 (ABN AMRO), r.o. 4.5. 
daaraan verbonden onderneming voorop behoort te stellen en de belangen van alle betrokkenen, waaronder die van de aandeelhouders, bij zijn besluitvorming in aanmerking behoort te nemen. ${ }^{55}$ Voorts is het bestuur onder omstandigheden gehouden de gerechtvaardigde belangen van potentiële ('serieuze') bieders te respecteren en dient zich te onthouden van maatregelen die mogelijke biedingen kunnen frustreren en de belangen van de desbetreffende bieders onevenredig kunnen schaden, bijvoorbeeld doordat deze een level playing field illusoir maken. ${ }^{56}$ Uit het feit dat bepaalde aandeelhouders het oneens zijn met het beleid van het bestuur en de RvC kan niet zonder meer volgen dat het bestuur gehouden is op de visie van die externe aandeelhouders in te gaan en door dat niet te doen blijk geeft van een defensieve en gesloten opstelling. ${ }^{57}$ Van twijfel aan een juist beleid zal voorts niet snel sprake zijn als het bestuur de dialoog met aandeelhouders is aangegaan en hun argumenten met goed onderbouwde en verdedigbare tegenargumenten heeft verworpen. ${ }^{58}$ Dit lijkt zelfs te gelden als het standalonescenario minder aandeelhouderswaarde genereert (op de lange termijn) dan het overnamevoorstel (op de korte termijn). ${ }^{59}$ Het aandeelhoudersbelang alleen is namelijk niet beslissend in Nederland. Ten slotte, de omstandigheid dat een belangrijk bedrijfsonderdeel wordt verkocht, terwijl sprake is van een overnamesituatie waarbij de potentiële bieder mede geïnteresseerd is in de verwerving van dat belangrijke bedrijfsonderdeel, kan niet zonder dat de wet of de statuten daarin voorzien leiden tot een goedkeuringsrecht of consultatierecht van de algemene vergadering. ${ }^{60}$

Er bestaat naar het oordeel van de Ondernemingskamer in AkzoNobel voorts geen algemene rechtsregel die een doelvennootschap ertoe verplicht inhoudelijke besprekingen te voeren met een serieuze potentiële bieder die ongevraagd een serieus overnamevoorstel doet. Of er inhoudelijk wordt gesproken met een spontane bieder hangt af van de omstandigheden van het concrete geval. Als er geen strategisch besluit is genomen om het standalone-scenario te verlaten, zijn blijkens de AkzoNobel-uitspraak de gezichtspunten om te spreken:

1 de voorgestelde biedprijs;

2 de strategische bedoelingen van de bieder;

3 de inhoud van de voorstellen van de bieder;

4 in hoeverre het bestuur van de targetvennootschap de voorstellen kan beoordelen zonder inhoudelijke besprekingen met de bieder; en

5 de inhoud en het verloop van de overige interactie tussen target en bieder. ${ }^{61}$

Voorts bestaat er blijkens de AkzoNobel-uitspraak jegens de potentiële bieder ook geen verplichting tot onderhandelen. De rechtsverhouding tussen de doelven- 
nootschap en de potentiële bieder wordt weliswaar in zoverre door de redelijkheid en billijkheid beheerst dat het bestuur van de doelvennootschap onder omstandigheden gehouden is de gerechtvaardigde belangen van potentiële ('serieuze') bieders te respecteren en zich te onthouden van maatregelen die mogelijke biedingen kunnen frustreren en de belangen van de desbetreffende bieders onevenredig kunnen schaden, ${ }^{62}$ maar dat geeft degene die ongevraagd een voorstel tot overname doet geen aanspraak op onderhandelingen met de doelvennootschap.

\subsection{Lessen uit de jurisprudentie: positie bieder}

Voor wat betreft de (potentiële) bieder tevens aandeelhouder heeft te gelden, mede gezien het bepaalde in art. 2:8 BW, dat deze als behoorlijk aandeelhouder in verband met en bij gelegenheid van de verkrijging van die aandelen (1) opening van zaken geeft, met de vennootschap wier aandelen hij verkrijgt (2) redelijk overleg pleegt, ${ }^{63}$ en in zijn handelen niet alleen zijn eigen belangen, maar ook (3) de belangen van de vennootschap in al haar facetten en de belangen van de bij de vennootschap betrokken personen betrekt. ${ }^{64}$ Als een doelvennootschap voorstellen van een potentiële bieder gemotiveerd afwijst, is het aan de bieder om aan de bezwaren en bedenkingen tegemoet te komen, bijvoorbeeld door het verschaffen van meer informatie. ${ }^{65}$

In de praktijk zal een vijandige bieding, dat wil zeggen een bieding waar het bestuur van de target niet aan meewerkt, niet zo snel plaatsvinden. Dat komt omdat:

a andere stakeholders, waaronder andere aandeelhouders, zich dan mogelijk ook (meer) kritisch opstellen;

b M\&A litigation en/of beschermingsmaatregelen mogelijk ingezet kunnen worden;

c due diligence en informatieverkrijging gebrekkig zal zijn of zelfs achterwege blijft;

d eventuele financiering van het bod lastiger kan worden; en

e medewerking van de target bij de te doorlopen procedure, ook bijvoorbeeld op het terrein van het mededingingsrecht, eveneens doorgaans niet voor de hand ligt.

\subsection{Lessen uit de jurisprudentie: enkele conclusies}

Uit het voorgaande blijkt mijns inziens dat (1) de gang naar de Ondernemingskamer kan helpen als het gaat om onwelkome (potentiële) bieders en/of aandeelhoudersactivisme; (2) het bestuur naar huidig recht al de nodige ruimte en vrij-

62 Zo ook al HR 13 juli 2007, ECLI:NL:HR:2007:BA7970 (ABN AMRO), r.o. 4.6.

63 In Hof Amsterdam (OK) 11 maart 1999, NJ 1999/351 (Breevast) constateerde de Ondernemingskamer dat hier niet aan werd voldaan. De eigen opstelling van de verwerver getuigde niet van bereidheid tot overleg, maar veeleer leek het dat de verwerver de gang van zaken wenste voor te schrijven en wel zonder dat zij haar voornemens met de vennootschap overigens voldoende uiteenzette.

64 Hof Amsterdam (OK) 3 maart 1999, NJ 1999/350 (Gucci I), r.o. 3.3.

65 Hof Amsterdam (OK) 29 mei 2017, ECLI:NL:GHAMS:2017:1965 (AkzoNobel), r.o. 3.22. 
heid heeft om zich te verweren tegen activistische aandeelhouders en niet-welkome (potentiële) bieders; (3) van twijfel aan een juist beleid niet snel sprake zal zijn als het bestuur de dialoog met aandeelhouders is aangegaan en hun argumenten met goed onderbouwde en verdedigbare tegenargumenten heeft verworpen aan de hand van een logische en verdedigbare strategie die breed wordt gesteund door de betrokken stakeholders, dit ook gelet op de doorgaans marginale rechterlijke toetsing, en dit lijkt zelfs te gelden wanneer het standalone-scenario minder aandeelhouderswaarde genereert (op de lange termijn) dan het overnamevoorstel (op de korte termijn); (4) de rechten en mogelijkheden van activistische aandeelhouders en niet-welkome (potentiële) bieders grenzen kennen; en (5) een vijandige bieding, dat wil zeggen een bieding waar het bestuur van de target niet aan meewerkt, niet zo snel zal plaatsvinden.

\section{Is meer bescherming wenselijk?}

De vraag naar bescherming van beursfondsen hangt samen met het spanningsveld dat kan bestaan tussen aandeelhouders en het bestuur van de vennootschap. ${ }^{66}$ Dit spanningsveld vindt mede zijn oorsprong in de nv-wetgeving die in 1929 van kracht werd. Destijds was de heersende opvatting nog dat de aandeelhouders de hoogste macht vormden en dat de vennootschap een contract was. Derhalve was het toen logisch dat de aandeelhouders krachtige zeggenschapsrechten toekwamen. De sporen van die thans verlaten theorie - nu is sprake van de vennootschap als instituut en het vennootschappelijk belang als basis om rekening te houden met de belangen van alle stakeholders - zijn evenwel nog steeds duidelijk te zien. In principe heeft de algemene vergadering immers nog steeds de bevoegdheid bestuurders te benoemen, schorsen en ontslaan. ${ }^{67}$ Dat betekent dat een potentiële bieder en/of activistische aandeelhouder nogal eens zal proberen - hetgeen ook bij AkzoNobel het geval was - om de bestuurders en/of commissarissen de wacht aan te zeggen. Onder andere het agenderingsrecht en het enquêterecht worden daarbij nogal eens gehanteerd. Het bestuur van de doelvennootschap dient evenwel, zo is de gedachte, niet te worden belemmerd in zijn taak te takeover regulation, Oxford: Oxford University Press 2016, hoofdstuk XI.

67 De rechtspraak biedt wel enige handvatten om hier de harde randjes vanaf te halen. Zie in dit kader de uitspraak van Hof Amsterdam (OK) 27 mei 2010, ECLI:NL:GHAMS:2010:BM5928 (PCM), waarin de Ondernemingskamer overwoog: '3.13 (...) De Ondernemingskamer merkt voorts op dat, mede gelet op hetgeen ingevolge artikel 2:8 BW naar maatstaven van redelijkheid en billijkheid wordt gevorderd, voor de private equity partij die zich aandient als toekomstig aandeelhouder in een vennootschap op een wijze als de onderhavige, heeft te gelden, dat zij in haar handelen dat verband houdt met het verkrijgen van een belang als het onderhavige in de doelvennootschap, niet alleen de eigen belangen maar ook de hiervoor in 3.2 vermelde onderscheiden vennootschappelijke belangen dient te betrekken.' Voorts noem ik HR 12 juli 2013, ECLI:NL:HR: 2013:BZ9145 (VEB/KLM). Ik citeer: 'Nu de houders van prioriteitsaandelen grootaandeelhouder waren in de algemene vergadering van gewone aandeelhouders die op 3 juli 2008 besluit B nam, neemt onderdeel 4.3 terecht tot uitgangspunt dat zij bij het nemen van besluit A de nodige zorgvuldigheid met betrekking tot de belangen van minderheidsaandeelhouders zoals VEB c.s. moesten betrachten.' Men zou dit een zwaardere 'duty of care' kunnen noemen. 
handelen in het belang van de vennootschap en de met haar verbonden onderneming. Is sprake van een bod waarvan het bestuur tot de conclusie kan komen dat dit niet in het belang van de vennootschap is, dan moet hij zich hiertegen kunnen verzetten. De mogelijkheid beschermingsmaatregelen te treffen versterkt de onderhandelingspositie van het bestuur tegenover de overnemer. Uit een recent onderzoek van Chammanur en Tian blijkt dat een beschermingsmaatregel inderdaad in een competitieve omgeving positieve effecten kan hebben, omdat deze het bestuur beter in staat stelt een innovatieve en langetermijnstrategie te voeren, aangezien het bestuur minder wordt blootgesteld aan de druk van aandeelhouders die op de korte termijn rendementen proberen te behalen. ${ }^{68}$ In het bijzonder indien een overnemer slechts kortetermijnresultaten nastreeft en daar het ondernemingsbeleid op wil baseren, heeft het bestuur de taak de langetermijnstrategie niet uit het oog te verliezen. ${ }^{69}$ Het is echter ook niet wenselijk dat een overname die het economische belang van de doelwitvennootschap dient achterwege blijft vanwege beschermingsmaatregelen. Creëren overnames overigens in de regel extra waarde? Volgens de Kay Review blijkt dat een 'substantial body of academic evidence suggests that little of value is added to business by merger activity' $^{70}$

Het is dus niet per se onlogisch dat het bestuur zich kritisch opstelt als een potentiële bieder zich aanmeldt. Ook omdat zelfs een geslaagde overname negatieve effecten kan hebben. Dat blijkt goed uit een andere zaak waar AkzoNobel bij betrokken was. ${ }^{71}$ Uit een studie over het Engelse bedrijf Courtaulds, overgenomen door AkzoNobel in 1998, blijkt hoe Courtaulds als gevolg van diverse foute keuzes een 'unwieldly conglomerate' was geworden. AkzoNobel slaagde er na overname in om het bedrijf weer tot leven te wekken, onder meer door de vezeltak te verkopen en de focus te leggen op verfactiviteiten. Het positieve gevolg was dat beide activiteiten succesvol en levensvatbaar konden worden voortgezet. De negatieve kant van het verhaal was - mede door het wegvallen van de hoofdkantoorfunctie - het effect op de lokale werknemers, afhankelijke lokale bedrijven, de lokale gemeenschap en op onderzoek en ontwikkeling (R\&D). ${ }^{72}$

Het spanningsveld lijkt bovendien te zijn toegenomen als gevolg van de toename van activistische aandeelhouders, onder meer uit het Verenigd Koninkrijk en de

68 T. Chammanur \& X. Tian, Do anti-takeover provisions spur corporate innovation?, www.ssrn. com, p. 3-4. Zo ook A. Kacperczyk, 'With greater power comes greater responsibility: Takeover protection and corporate attention to stakeholders', Strategic Management Journal (30) 2009, afl. 3, p. 261-285.

69 Zie Kamerstukken II 1997/98, 25732, 3, p. 2-3.

70 Kay review of UK equity markets and long term decision making, juli 2010, p. 58. Zie voor een soortgelijk geluid ook E.J.J. Schenk, 'Bezint eer ge begint', Ondernemingsrecht 2014/125 en E.J.J. Schenk, 'Verreweg de meeste fusies mislukken', NRC Handelsblad 19 januari 2013.

71 Vermeldenswaard is voorts dat AkzoNobel zelf in 2008 zonder grote protesten de grootste industriële beursonderneming in het Verenigd Koninkrijk, Imperial Chemical Industries, heeft kunnen overnemen.

72 G. Owen, The rise and fall of great companies: Courtaulds and the reshaping of the man-made fibres industry, Oxford: Oxford University Press 2010. 
Verenigde Staten, die (mede)zeggenschap eisen over de strategie en strategiewijzigingen pogen af te dwingen. Inmiddels zouden buitenlandse beleggers volgens VEUO en VNO-NCW vrijwel $90 \%$ van het aandeelhoudersbestand van Nederlandse beursvennootschappen vormen. ${ }^{73}$ Vanaf de jaren zeventig van de vorige eeuw gingen Nederlandse bedrijven bovendien steeds vaker in het buitenland investeren en minder in Nederland, terwijl buitenlandse bedrijven (meer) in Nederland gingen investeren. ${ }^{74}$ Daarnaast is van belang dat de afgelopen decennia de importantie van aandeelhouders met grotere belangen is afgenomen en er nu veel meer beursvennootschappen zijn met vooral aandeelhouders met kleine belangen. ${ }^{75}$ Ook de invloed van rijke families en vermogende individuen als aandeelhouder is afgenomen, terwijl Nederlandse institutionele investeerders - door de internationalisering van de financiële markten - steeds meer in buitenlandse bedrijven beleggen en voorts meer spreiding aanbrengen in hun beleggingen. Ook namen kruiselingse belangen af. Dit betrof ook belangen gehouden door buitenlandse beursondernemingen met veelal een langetermijnpolitiek als aandeelhouder. ${ }^{76}$ Daarnaast kennen steeds meer beursvennootschappen bestuurders en/of commissarissen met een buitenlandse nationaliteit. Dit alles leidde tot een minder hechte eenheid van financieel-economische elites in Nederland. ${ }^{77}$ Dit werd nog versterkt door de afname van het gebruik van beschermingsconstructies en de idee, begin 2000, dat aandeelhouders meer te zeggen moeten krijgen. ${ }^{78}$ Voorts heeft een verschuiving plaatsgevonden van individuele investeerders naar professionele - binnenlandse en vooral buitenlandse - beleggers. Deze professionele beleggers worden nogal eens gestimuleerd of voelen een bepaalde druk om vaker te handelen - kortetermijnfocus - dan individuele investeerders (mogelijk) zouden doen.

De gedachte is dat de focus van beursondernemingen zou moeten liggen op langetermijnwaardecreatie, omdat kortetermijnfocus schadelijk kan zijn voor onderne-

Zie Kamerstukken II 2016/17, 29752, 9, p. 9 (Nota voortgang modernisering ondernemingsrecht).

74 Zie hierover F.G.K. Overkleeft, De positie van aandeelhouders in beursvennootschappen, Deventer: Wolters Kluwer 2017, p. 89.

75 Zo kende in 1992 nog 41\% van de beursvennootschappen een aandeelhouder met een belang van $30 \%$ of meer. In 2005 was dat nog maar 26\%. Zie G. Westerhuis \& A. de Jong, Over geld en macht. Financiering en corporate governance van het Nederlandse bedrijfsleven, Amsterdam: Boom 2015, p. 182. Overigens zou volgens Eumedion in de laatste jaren van een toegenomen concentratie van aandelen bij Nederlandse beursvennootschappen sprake zijn. Het aantal van deze vennootschappen dat een aandeelhouder met een wezenlijk aandelenbelang kent (tussen de $10 \%$ en $30 \%$ van de stemrechten), zou met ongeveer $50 \%$ zijn gestegen. Ook het aantal vennootschappen met een controlerend aandeelhouder (een aandeelhouder die meer dan $30 \%$ van de stemrechten heeft) zou sterk gestegen zijn. Zie Position Paper Eumedion van 28 juni 2016, 'Positie minderheidsaandeelhouders in ondernemingen met een controlerend aandeelhouder'.

76 Zie hierover Overkleeft 2017, p. 113.

77 Zie over de invloed van maatschappelijke veranderingen ook D.C. North, Institutions, institutional change and economic performance, Cambridge: Cambridge University Press 1990.

78 Dat heeft tot enkele wetsaanpassingen geleid, zoals het agenderingsrecht van aandeelhouders, het goedkeuringsrecht van de algemene vergadering ten aanzien van belangrijke bestuursbesluiten en de stemvolmacht voor certificaathouders (wetsvoorstel structuurregeling). 
mingen. ${ }^{79}$ Aandeelhouders met een kortetermijnperspectief zijn wat dat betreft meer vergelijkbaar met huurders. Deze personen hebben doorgaans niet de belangrijkste bevoegdheden met betrekking tot de woning die ze huren. Dat zou voor ondernemingen ook kunnen gelden. Om kortetermijngedrag tegen te gaan heeft bijvoorbeeld de Financial Reporting Council in het Verenigd Koninkrijk in 2010 een Stewardship Code opgesteld. Dit om aandeelhouders meer betrokken te laten zijn bij de corporate governance van ondernemingen. Het verwachten van stewardshipgedrag door aandeelhouders is evenwel niet (altijd) realistisch en dit mag wellicht ook niet altijd worden verwacht. ${ }^{80}$ Zo kunnen institutionele investeerders dat veelal niet, onder andere door het grote aantal bedrijven waar ze in beleggen en de aan het actief monitoren verbonden kosten. Mocht aandelenhandel met behulp van blockchain een vlucht gaan nemen, dan zal dit leiden tot lagere kosten en transacties die sneller tot stand komen. Het is de vraag of dit zal bijdragen aan stewardshipgedrag. In dit kader zou daarom nader kunnen worden onderzocht welke aandeelhouders meer een langetermijnfocus (bereid zijn te) hebben, ${ }^{81}$ en gepoogd kunnen worden dergelijke aandeelhouders (onder andere) meer te betrekken bij de formulering en invulling van de visie op langetermijnwaardecreatie en de strategie om deze visie te realiseren. Het gaat er daarbij ook om te bevorderen dat langetermijnaandeelhouders zo veel mogelijk werkelijk betekenisvolle betrokkenheid tonen bij de onderneming. Eenvoudig zal dat niet (altijd) zijn. Dit ook omdat de langetermijnaandeelhouders bij een mogelijk openbaar bod nogal eens niet op het bod wachten, maar hun aandelen al daarvoor verkopen en voor de kortetermijnwinst gaan. Dat betekent dat het aantal kortetermijnaandeelhouders - die veelal voor een prijs onder de biedprijs hebben gekocht en erop speculeren dat ze op korte termijn voor de hogere biedprijs kunnen verkopen - ten tijde van het bod meer invloed heeft. Mogelijkheden als loyaliteitsaandelen kunnen wellicht behulpzaam zijn bij het terugdringen van de invloed van dergelijke kortetermijnaandeelhouders. ${ }^{82}$ In de praktijk zal men zijn weg moeten vinden. Ook omdat de samenleving, mede onder invloed van globalisering, constant aan verandering onderhevig is. ${ }^{83}$ Het verleden keert niet terug en

79 In de woorden van Chandler: 'The rapidity with which a number of capital-intensive industries in the United States - those that have been driven industrial growth - have lost market share at home and abroad since the merger and acquisition wave of the 1960s suggests that, in those American industries at least, long-term investment may have been sacrificed for short-term gain.' Zie A.D. Chandler Jr, Scale and scope. The dynamics of industrial capitalism, Cambridge, MA: Harvard University Press 1994, p. 627.

80 Zie hierover J. Noguera, 'Institutional investors and the Stewardship Code: An analysis of why institutional investors do not monitor or engage', International Company and Commercial Law Review (28) 2017, afl. 3.

81 Zie hierover W.B. Kuijpers, 'Onderzoek korte termijngedrag Nederlandse institutionele beleggers', Ondernemingsrecht 2013/106.

82 Het is wel de vraag of de algemene vergadering hieraan mee zal willen werken. Immers, de loyaliteitsregeling kan consequenties hebben voor de verhandelbaarheid van de aandelen gedurende de voorfase van een mogelijk openbaar bod.

83 Useem zegt hierover: 'But the emergence of institutional capitalism and classwide principles of organization have introduced still different rules. The firm remains a primary unit of action, but the transcorporate network becomes a quasi-autonomous actor in its own right.' M. Useem, The inner circle, Oxford: Oxford University Press 1984, p. 195. 
aandeelhoudersactivisme lijkt een blijvend fenomeen. ${ }^{84}$ Keerzijde is dat het ondernemingen en hun besturen scherp houdt. Daarbij is van belang dat van twijfel aan een juist beleid niet snel sprake zal zijn als het bestuur de dialoog met aandeelhouders is aangegaan en hun argumenten met goed onderbouwde en verdedigbare tegenargumenten heeft verworpen aan de hand van een logische en verdedigbare strategie die breed wordt gesteund door de betrokken stakeholders. Daarnaast is van groot belang dat het bestuur adequaat verantwoording aflegt aan de algemene vergadering. ${ }^{85}$ Hier liggen denk ik belangrijke taken voor besturen.

Ondertussen heeft het nieuwe kabinet in het regeerakkoord een voorstel opgenomen voor bedenktijd. Dit is als volgt omschreven:

'Een beursgenoteerde onderneming die op de Algemene Vergadering van Aandeelhouders (AvA) te maken krijgt met voorstellen voor een fundamentele strategiewijziging kan een bedenktijd van maximaal 250 dagen inroepen, mits deze het kapitaalverkeer niet raakt. In deze periode dient verantwoording te worden afgelegd aan de aandeelhouders over het gevoerde beleid en dienen alle stakeholders die betrokken zijn bij de onderneming, geraadpleegd te worden. Deze maatregel kan niet worden ingezet in combinatie met beschermingsconstructies van bedrijven zelf, zoals de uitgifte van preferente aandelen of prioriteitsaandelen.'

Het is de vraag of dit veel toevoegt voor onbeschermde ${ }^{86}$ beursvennootschappen, zeker nu de Code al de mogelijkheid biedt voor een responstijd van maximaal 180 dagen. ${ }^{87}$ Mijns inziens lijkt de nu al bestaande mogelijkheid om de Onderne-

84 Beatty zegt hierover: 'Fortune 500 companies now have at least two to five activist firms looking at them. If there's the slightest suggestion that a listed company is slow (...), compared to its rivals, and has an inflated cost base, activists will be all over them.' D. Beatty, University of Toronto, kenbaar uit: T. Featherstone, Governance in the new machine age, Australian Institute of Company Directors, 24 maart 2017, online te raadplegen op aicd.companydirectors.com.au/ advocacy/governance-leadership-centre/governance-drivingperformance/governance-in-thenew-machine-age. Zie voorts ook 'Beleggers die blaffen én bijten', NRC 18 november 2017. Hof Amsterdam (OK) 29 mei 2017, ECLI:NL:GHAMS:2017:1965 (AkzoNobel), r.o. 3.26-3.37.

86 Overigens beschikt ruim 75\% van de AEX- en AMX-fondsen over een beschermingsconstructie. Zie 'Toverdoos van beschermingsconstructies', FD 12 april 2017.

87 Zie best practice bepaling 4.1.6: '(...) Wanneer één of meer aandeelhouders het voornemen hebben de agendering te verzoeken van een onderwerp dat kan leiden tot wijziging van de strategie van de vennootschap, bijvoorbeeld door het ontslag van één of meer bestuurders of commissarissen, wordt het bestuur in de gelegenheid gesteld een redelijke termijn in te roepen om hierop te reageren (de responstijd).' De Ondernemingskamer heeft in 2013 in een zaak geoordeeld dat de responstijd terecht was ingeroepen (Hof Amsterdam (OK) 6 september 2013, ECLI:NL:GHAMS: 2013:2836 (Cryo-Save)). Er bestaat in de literatuur wel discussie in hoeverre deze uitspraak juist is. Instemmend zijn onder meer M.W. Josephus Jitta in zijn JOR-noot (JOR 2013/272) en H-J. de Kluiver, 'Reactie op commentaar bij uitspraak Cryo-Save Group/Salveo Holding', Ondernemingsrecht 2013/127. Afwijzend is onder meer R. Abma, 'Naschrift bij reactie Harm-Jan de Kluiver', Ondernemingsrecht 2013/128. Onduidelijk is (voorts) of deze responstijd strijdig is met de Aandeelhoudersrichtlijn. Zie daarover F. Eikelboom, De (onmiddellijke) voorzieningen van de enquêteprocedure, Deventer: Wolters Kluwer 2017, p. 219 en 220. 
mingskamer om hulp te vragen een redelijk en bruikbaar middel. ${ }^{88}$ De Ondernemingskamer kan immers na een gedegen - en als het moet tevens snelle - afweging op grond van twijfel aan een juiste gang van zaken of juist beleid besluiten onmiddellijke voorzieningen te bevelen - zoals het schorsen van stemrecht - en daarnaast (mogelijk) een onderzoek gelasten. Dit lijkt mij een proportionelere ${ }^{89}$ oplossing dan om elke onderneming, ook waar het een puinhoop is geworden, 250 dagen te geven. Dit ook omdat dat ertoe kan leiden dat een potentiële bieder wegloopt. Dergelijke beïnvloeding van de marktwerking moeten we mijns inziens niet willen. Daarbij is ook van belang dat activistische aandeelhouders een nuttige functie kunnen vervullen door het bestuur van een beursvennootschap scherp te houden. Boeiend is in dat kader dat AkzoNobel ondertussen de strategie heeft aangepast, doordat de chemietak wordt afgesplitst. Daarnaast lijkt AkzoNobel zelf op het overnamepad te zijn. ${ }^{90}$ Een nog te beantwoorden vraag is wat de aandeelhouders op de lange termijn hiervan zullen vinden. ${ }^{91}$

Dat neemt niet weg dat verder nagedacht kan worden over mogelijkheden zoals loyaliteitsaandelen, evenals over regulering van het gedrag van aandeelhouders en intermediairs via het financiële recht. ${ }^{92}$ Ten slotte kan ook verder worden nagedacht over de mogelijkheid om de Nederlandse activiteiten in een aparte subholding onder te brengen, waarop het structuurregime van toepassing is.

\section{Conclusie}

De conclusie luidt mijns inziens dat het voorstel van het nieuwe kabinet voor bedenktijd achterwege kan blijven. De nu al bestaande mogelijkheden, waaronder de optie om de hulp van de Ondernemingskamer in te roepen, vormen naar mijn mening een redelijke en bruikbare systematiek en deze kunnen bovendien tot een proportionele oplossing leiden. ${ }^{93}$ Soms is niets doen ook een oplossing. Maar dat wist $\mathrm{u}$ al wel, vermoed ik.

88 Zo ook M.W. Josephus Jitta, 'Een “nieuwe” rol voor de Ondernemingskamer?', Ondernemingsrecht 2017/62.

89 De Kluiver lijkt positiever te oordelen over dit voorstel. Zie H.J. de Kluiver, 'Modernisering ondernemingsrecht; waarheen, waarvoor?', Ondernemingsrecht 2017/118. Dit (mede) omdat de Code-bepaling geen directe binding van aandeelhouders kent en de regeling afhankelijk kan zijn van een rechterlijke procedure. Met een heldere wettelijke regeling worden dergelijke procedures, en de enorme afleiding en onzekerheid die deze meebrengen, nu juist voorkomen, zo meent De Kluiver.

90 Zie 'AkzoNobel paait aandeelhouders met hoger dividend en opbrengst chemiedivisie', FD 19 april 2017, en 'AkzoNobel waardeert Axalta op \$44 per aandeel’, FD 5 december 2017.

91 Op korte termijn lijkt in elk geval niet iedereen tevreden. Zie 'Hoe AkzoNobel zich van zijn aandeelhouders vervreemdde', FD 8 september 2017.

92 Zie daarover I.H-Y. Chiu \& D. Katelouzou, Making a case for regulating institutional shareholders' corporate governance roles, www.ssrn.com, 2017.

93 Zo ook H.M. Vletter-van Dort \& T.A. Keijzer, 'De veilige toekomst van de Nederlandse beursvennootschap', Ondernemingsrecht 2017/73. 